\title{
Chłopcy malowani (piórem Andrzeja Struga i Miroslava Krležy). Etiuda komparatystyczna
}

\section{The painted boys (Andrzej Strug and Miroslav Krleža' pen). A comparative study}

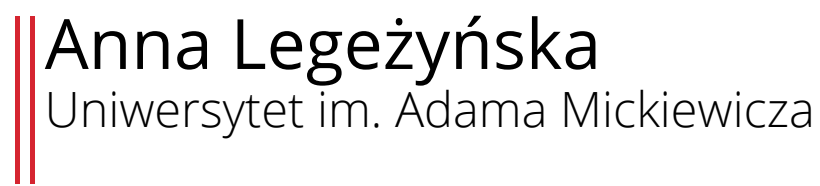

\begin{abstract}
The main subject of the article is a diverse image of the generation of World War I in Polish and Balkan literature. The two works which have been a subject of the comparative study are Badge of Loyal Service by Andrzej Strug and the novel Domobran Jambrek by Miroslaw Krleža (a part of Croatian God Mars). The author explains the principles and functions of pompous poetics of the description of war in the prose by Strug and in a completely different, ironic poetics of the stories by Krleža. Despite many similarities, the two works transmit different artistic and political ideologies. In the last part of the article, another point of reference to the subject of war is a novel by Serbian writer Miloš Crnjanski: Records of Czarnojevic. In the conclusion of her considerations, the author points to the diversity of contexts of tradition and draws attention to the importance of formative function of Polish Romanticism.
\end{abstract}

Key words: World War I, lost generation, Polish prose, Balkan prose, comparative analysis, pathos, irony, grotesque.

Streszczenie: Głównym tematem artykułu jest zróżnicowanie obrazu pokolenia I wojny światowej w literaturze polskiej i bałkańskiej. Przedmiotem przeprowadzonej analizy porównawczej stały się dwa utwory: Odznaka za wiernq służbę Andrzeja Struga oraz opowiadanie Ambrożek domobrońca (Domobran Jambrek) Miroslava Krležy z tomu Chorwacki bóg Mars. Autorka objaśnia zasady i funkcję patetycznej poetyki opisu wojny w prozie Struga oraz zupełnie odmiennej, ironicznej poetyki opowiadania Krležy. Mimo wielu podobieństw, oba utwory emitują odmienne ideologie artystyczne i polityczne. W zakończeniu artykułu kolejnym odniesieniem dla tematu wojennego jest powieść serbskiego pisarza, Miloša Crnjanskiego pt. Zapiski o Czarnojeviciu. W konkluzji rozważań autorka wskazuje na odmienność kontekstów tradycji i zwraca uwagę na formacyjne znaczenie polskiego romantyzmu.

Słowa kluczowe: I wojna światowa, stracone pokolenie, proza polska, proza bałkańska, analiza porównawcza, patos, ironia, groteska. 
Wojenko, wojenko, cóżeś ty za pani, Że ku tobie ida chłopcy malowani? Chłopcy malowani, chłopcy wybierani, Wojenko, wojenko, cóżeś ty za pani? ${ }^{1}$

Słynna piosenka legionowa, z której pochodzi przytoczony fragment, powstała prawdopodobnie w 1917 roku na kanwie innej pieśni, ludowej. „Chłopcy malowani” ginęli masowo na frontach Wielkiej Wojny, a ci, którzy przeżyli, trwali w duchowym - i nierzadko fizycznym - kalectwie, które było dramatem indywidualnych, zwykle regresywnych biografii, lecz i mocnym impulsem rozwojowym dla powojennej kultury. W literaturze Zachodu zostali później nazwani „straconym pokoleniem”. The Lost Generation, pokolenie zarażone wojną, przegrana generacja - tak określono bohaterów prozy pisarzy amerykańskich, którzy sami uczestniczyli w działaniach wojennych (jak Francis Scott Fitzgerald, John Dos Passos, Ernest Hemingway). Szerzej formuła odnosi się do świadomości pokoleniowej ludzi urodzonych ok. 1898 roku, dla których I wojna światowa stała się przeżyciem formacyjnym, opisywanym także przez twórców europejskich.

Jeden z pierwszych w literaturze zachodniej i swego czasu najgłośniejszych utworów przedstawiających wojnę z perspektywy uczestnika napisał urodzony w 1873 roku Henri Barbusse, dając mu tytuł Le feu (po polsku: Ogień $^{2}$. Na kształtowanie się europejskiej mitologii „straconego pokolenia" największy wpływ miał jednak Erich Maria Remarque, autor słynnej powieści pt. Im Westen nichts Neues ${ }^{3}$ (Na Zachodzie bez zmian) z 1929 roku. Pisarz otwierał ją wyjaśnieniem: „Książka ta nie ma być oskarżeniem ani też wyznaniem. Jej zamiarem jest tylko mówić o pokoleniu, które wojna zniszczyła - nawet gdy uchroniło się przed granatami" (Remarque 1974, 5).

Literacka mitologia „straconego pokolenia” została później także ugruntowana i poszerzona przez filmowe ekranizacje powieści Fitzgeralda (Wielki Gatsby), Hemingwaya (Pożegnanie z broniq), Remarque'a (Na Zachodzie bez zmian). Trzeba jednak przypomnieć, że jak każdy portret generacyjny, tak i mitologia The Lost Generation jest tylko najbardziej ogólnym, by nie powiedzieć: stereotypowym opisem formacji, która $\mathrm{w}$ różnych regionach Europy ma swoją bardziej szczegółową i geopolitycznie zdeterminowaną biografię. Bohaterowie wojennej prozy środkowoeuropejskiej tworzą także bardzo zróżnicowaną galerię postaci. „Chłopcy malowani” w polskiej

1 Źródło cytatu: http://bibliotekapiosenki.pl/Wojenka \%28piesn legionowa\%29. Data dostępu: 28.03.2016. Więcej informacji na temat genezy tekstu: http://historiez̄apomniane.blogspot.com/2012/02/polskie-piesni-wojenko-wojenko.html

2 Zob. Barbusse H., 1959, Ogień. Dziennik pewnego oddziału, Jaremko-Pytowska Z. (przeł.), Warszawa. Autor opatrzył tekst datą 1915, a publikował go w jednym z paryskich pism jeszcze podczas wojny w 1916 roku; pierwsze wydanie ukazało się w 1917 roku. Książka została uhonorowana Nagrodą Goncourtów i miała ponad 50 wydań w różnych językach.

3 Ukazując wojnę z perspektywy „zniszczonego” pokolenia, Remarque (niemiecki pisarz, którego książkę w hitlerowskich Niemczech w 1933 roku spalono) podobnie jak Barbusse wykorzystuje w swej narracji formę dziennika. Tworzy relację unaoczniającą uczestnika wojny, szeregowego członka małego żołnierskiego oddziału. 
literaturze są inni niż rekruci z powieści Remarque’a, inni też są młodzi żołnierze ukazywani w prozie bałkańskiej.

Dla rozpoznania tych różnic wybieram dwa utwory radykalnie odmienne w swych ideologicznych przesłaniach, powstałe w różnych językach, lecz w tym samym roku 1920. Oba teksty: literacki pamiętnik Andrzeja Struga (czyli Tadeusza Gałeckiego) pt. Odznaka za wierna służbę oraz opowiadanie Miroslava Krležy pt. Ambrożek domobrońca (Domobran Jambrek) z tomu Chorwacki bóg Mars są dziś rzadko przypominane, choć w kontekście problematyki pokoleniowo-historycznej wydają się reprezentatywne. Znajdziemy w nich podobną intencję gatunkową, ponieważ oba ukazują inicjacyjny charakter doświadczenia wojennego. Bohaterami utworów są szesnastoletni rekruci przywdziewający mundury obcej, austro-węgierskiej armii. Jeden z nich ma na imię Sylwek, drugi natomiast Jambrek (a w tłumaczeniu polskim Ambrożek). Losy chłopców odsłaniają dwa odmienne oblicza Wielkiej Wojny.

1.

Obaj pisarze brali w niej czynny udział, choć w zupełnie różnych regionach Europy. Andrzej Strug (1871-1937) bił się w legionach Józefa Piłsudskiego (w stopniu wachmistrza sztabowego), w latach 1915-1918 pełnił funkcję referenta politycznego w Polskiej Organizacji Wojskowej. Mirosłav Krleža (1893-1981) walczył na froncie w Galicji, później był dziennikarzem w Zagrzebiu. Z chwilą wybuchu wojny został wcielony do armii habsburskiej, w której Chorwaci przez dziesięciolecia przelewali krew za nie swoje sprawy. Bardzo możliwie, że obaj pisarze kiedyś nawet się spotkali, bo Krleža w międzywojniu przyjeżdżał do Polski, wiosnę 1932 roku spędził w Warszawie. Był tu pisarzem znanym (także z burzliwego romansu z Zofią Nałkowską). Jego nowele z czasów wojny w przekładzie Władysława Glucka i Haliny Siennickiej, z przedmową Juliusza Benešicia, opublikował Instytut Wydawniczy „Biblioteka Polska” w Warszawie w 1939 roku. Krleža w czasie wojny pisał sprawozdania frontowe, do wojennej tematyki powracał potem w wielu swoich utworach nasyconych ironią, lecz także realizmem. Jego „bóg Mars” jest okrutny, niszczycielski, bezideowy, absurdalny. Natomiast Andrzej Strug pisał o wojnie jako historycznym dramacie, który mimo ogromnych ofiar zakończył się dla Polaków odzyskaniem niepodległości. W 1920 roku, gdy powstały oba utwory, wojna była skończona, rozpoczynano obrachunki.

Odznaka za wierna służbę to niewielka opowieść poprowadzona w formie pamiętnika pisanego przez młodego rekruta ułańskiejjednostki Polaków w armii austro-węgierskiej, walczącej z Moskalami. Dowódcą pułku jest Władysław Belina-Prażmowski, pojawiają się też w utworze inne autentyczne postacie, na przykład Bolesław Wieniawa-Długoszowski, a przede

\footnotetext{
4 Prof. Julije Benešić (1883-1957) w międzywojennej Polsce redagował Bibliotekę Jugosłowiańską, w której ukazały się liczne przekłady prozy serbo-chorwackiej.
} 
wszystkim sam Józef Piłsudski, twórca Związku Strzeleckiego, którego drużyny weszły po wybuchu wojny w skład Legionów Polskich, kierowanych przez Komendanta. Miały one wkroczyć na ziemie Królestwa Polskiego wraz z armią austriacką, wypierając Rosjan. Pułk Beliny brał udział w całej kampanii legionowej od sierpnia 1914 roku, ale Sylwek uczestniczy w niej tylko do sierpnia 1916 roku. Trudne warunki polowe osłabiają młody organizm, toteż odniesiony na polu bitwy postrzał przyśpiesza rozwój gruźlicy, która prowadzi do śmierci.

W regularnych zapiskach Sylwka rozwijają się dwa plany fabularne: wojenna epopeja oraz zapis przyśpieszonego dojrzewania szesnastoletniego chłopca. To skrzyżowanie dokumentu historycznego z prozą inicjacyjną ma mocną podstawę autobiograficzną, ponieważ Strug znał realia wojenne z autopsji. Mapa wędrówki pułku zarysowana w Odznace... pokrywa się z historiografią wojny, a osobiste przeżycia Sylwka noszą cechy typowej biografii pokoleniowej. Utwór ma charakter parenetyczny, los bohatera tworzy wzór „wiernej służby”; idea patriotyczna wśród wartości kształtujących świadomość chłopca, takich jak idea braterstwa czy doświadczenia miłosne, zajmuje miejsce nadrzędne. $\mathrm{W}$ tle wydarzeń i decyzji wojennych wciąż pojawia się postać Komendanta; w kolejnych epizodach Sylwek ma okazję znaleźć się blisko wodza, który mimo narastającej realności staje się postacią coraz bardziej mityzowaną, w swym heroizmie i mądrości wręcz nadludzką. Tuż przed śmiercią pozostający na skraju wyczerpania chłopiec dociera na peron, z którego miał odjechać przywódca, by zaznać zgoła mistycznego ukojenia:

Co za szczęście! Komendant spojrzał na mnie przechodząc tak przenikliwie i głęboko, a ja cały zamarłem. Tym jednym spojrzeniem wszystko mi powiedział, jakbym to usłyszał słowo po słowie.

„Umierasz, chłopcze? To dobrze, bo tak trzeba. Wielu was zginęło za Polskę, wielu jeszcze zginie. I jam gotów."

Oto spojrzenie Wodza. A mnie nie trzeba ani uznania, ani pociechy. On wszystko wie, co ja czuję, a ja czuję, że on o mnie wie (Strug 1957, 135).

Patos tej sceny - podobnie jak wielu innych - nie jest efektem pisarskiej nieudolności, lecz instrumentem działania perswazyjnego. Strug oczywiście analizuje psychologię dojrzewania i metamorfozy człowieka w warunkach wojennych, ale przede wszystkim realizuje świadomie - tak sądzę propagandowy cel książki. Opublikowana w 1920 roku, czyli wkrótce po odzyskaniu wolności, ma ona pozytywnie, a nawet afirmacyjnie usposobić czytelnika do postaci Piłsudskiego jako głównego projektanta kształtu niepodległości. Osobisty kult Komendanta dyktuje pisarzowi retorykę wzniosłości, realizowaną za pomocą patosu i afektywnego „nacisku” na czytelnika, wzruszonego męstwem, hartem ducha i szlachetnością młodego bohatera, dla którego najcenniejszą żołnierską „odznaką” staje się spojrzenie wodza. Wierność jako najwyższa cnota etosu rycerskiego jest głównym depozytem 
moralnym przekazanym pokoleniu Sylwka przez poprzedników (nad losem chłopca-sieroty dyskretnie czuwa kochająca babka, żarliwa patriotka).

Nie znaczy to, że Strug w całości idealizuje panoramę wojny. W zapiskach Sylwka, najpierw dość niefrasobliwie traktującego wojenne zagrożenia, narastają obrazy męki ludzi i zwierząt (koni), pojawiają się opisy cierpień i śmierci. Początkowo ta relacja pamiętnikarska odbija stan świadomości chłopca, którego widzenie świata ukształtowały, jak wolno domniemywać, ideowo-estetyczne klisze, co poświadcza poetyka takich oto opisów:

Zimna wichura jesienna, błotniste drogi, przemokłe wioski, strugi rozlane, krzyże przydrożne i aleje wielkich topoli szumiących resztkami liści... Wy, zarośla, wy, kępy leśne, w których przesiaduje zaczajony nieprzyjaciel... Ziemio ojczysta, smutna i stratowana wojną, ty jesteś Polską prawdziwą i szczerą... Ciemny i śpiący lud jest teraz nieszczęsny i struchlały. Ale nie odmówi chłop żołnierzowi polskiemu łyżki barszczu i tej miski kartofli i rad posłucha, co opowiada żołnierz wędrowny, który wieczorem niespodzianie zjeżdża do wsi, a o świtaniu już go nie ma (Strug 1957, 33).

Chciałoby się ten opis nazwać czystą, wydestylowaną do postaci stylistycznego stereotypu „żeromszczyzną". Sylwek zresztą utrwala w innym miejscu scenę spotkania Żeromskiego w zakopiańskiej kawiarni, wyznając: „Z uwielbieniem wpatrywałem się w największego w Polsce pisarza” (Strug 1957, 115). Dalej zaś komentuje niechęć autora Popiołów do legionistów jako efekt nieznajomości „naszego ducha”:

Niechby on się raz rozgadał z naszymi chłopakami. Choć przez jeden dzień pobył $\mathrm{z}$ nami na froncie. Na pewno otworzyłoby się ku nam jego kochające serce, to samo polskie serce, z którego wyszła opowieść o żołnierzu tułaczu (Strug 1957, 117).

Idealizacja legionowych przywódców i towarzyszy broni nie przesłania Sylwkowi prawdy o wojennych okropieństwach, a nawet - przez kontrast je potęguje. Zaraz pod notatką na temat „kochającego serca” Żeromskiego pojawia się zapis snów, pełnych koszmarnych reminiscencji jawy:

Oh, ci żołnierze!... Okrwawieni, obdarci, na pół zgnili. Wiszą na nich łachmany czerwonego mięsa, urwane ręce i nogi, niektórzy stoją na baczność, a bez głów! I nie ci byli najstraszniejsi, ale właśnie tacy, którzy patrzyli okropnymi, martwymi oczami i wyszczerzali zęby, jak to często bywa u zabitych (Strug 1957, 117).

Takich przedstawień w Odznace za wierna służbę znajdziemy więcej; traumatyczne wspomnienia będą też nękać bohaterów innej, bardziej znanej powieści Struga pt. Pokolenie Marka Świdy z 1925 roku (w której pisarz zresztą powtórzy i rozwinie pewne motywy z pamiętnika Sylwka). Poetyka opisów wojennej śmierci jest dla wszystkich pisarzy podejmujących ten temat wielkim wyzwaniem. Szukają oni zatem inspiracji w zasobach istniejących konwencji (naturalizmu) lub podejmują eksperymenty formalne, przede wszystkim uruchamiając techniki reporterskie (jak Barbusse w Ogniu).

Interesującym problemem warsztatowym jest w utworze Struga poszukiwanie balansu między ideową schematyzacją a psychologiczną 
wiarygodnością postaci. Sylwek uosabia „plakatowe” cechy młodego Polaka-patrioty i zarazem pogrąża się w autorefleksyjnych rozmyślaniach, próbując zracjonalizować zachodzące w nim samym przemiany osobowości. Zdaje sobie sprawę z inicjacyjnego charakteru własnych doświadczeń, z których najsilniejsze są spotkania z cudzą śmiercią (najpierw ukochanej klaczy Lucyny, potem bliskich kolegów) oraz wtajemniczenia erotyczne (pierwszy akt seksualny z urodziwą chłopką Łeńką), a następnie silne wzruszenia miłosne (platoniczny epizod z panią Hanką, wojenną wdową). Krótko przed śmiercią Sylwek doznaje uczucia epifanijnej jasności:

Aż pewnej nocy obudziłem się nagle, jakby mnie ktoś trącił. Natychmiast usiadłem na łóżku i zacząłem się sam sobie dziwować. Od razu wszystko, com przeżył, zaczęło mi się wydawać inne i większe. Wyglądało na to, żem nie rozumiał ani siebie, ani wojny aż do tej chwili ocknienia. Po prostu przejrzałem na oczy, jak gdybym dopiero zobaczył to, o czym dotąd tylko słyszałem i wyobrażałem sobie, a i to zaledwie mętnie i fałszywie (Strug 1957, 111).

Na początku relacji 16-letni chłopiec traktuje wojnę jak rodzaj przygody, śmierć nie czyni w jego psychice spustoszenia, a główną motywację do walki znajduje w kulcie Komendanta. Pisze: „Nas trzyma idea, nie regulamin" (Strug 1957, 25). Idea to niepodległość Polski. Świat według Sylwka dzieli się więc na armie wrogie (jak rosyjska) i chwilowo w walce o niepodległość pomocne (jak austriacka i niemiecka); nie ma w tym obrazie losu jednostkowego. Dopiero w drugim roku walki autor pamiętnika częściej notuje stany, świadczące o pogłębionej refleksji nad tym, co przeżywa. Mnoży makabryczne opisy śmierci, trupów, rozkładu; pisze: „nerwy mam nadpsute” (Strug 1957, 104). Sylwek odkrywa, że „nie rozumiał” wojny, nie czuł strachu, ale też nie czuł żalu po zabitych kolegach. Teraz „wszystko, co przeżył, zaczęło mi się wydawać inne i większe”. Dopiero w zakończeniu utworu młody żołnierz pojmuje, że oprócz aspektu patriotycznego, wojna ma także wymiar eschatologiczny, jednak to nie burzy jego skali wartości.

Temat wojny w Odznace za wierna służbe pełni funkcję perswazyjną, ale nie łączy się z rewelacją formy. Strug nadaje swej prozie cechy autentyku przez narrację pamiętnikarską prowadzoną w pierwszej osobie, jednak nie podejmuje żadnych eksperymentów formalnych - choć potencjalna w tym utworze struktura powieści rozwojowej mogłaby zostać umocniona przez pogłębienie psychologizmu. Głównym celem było jednak przekonanie czytelnika o wartości najważniejszego projektu etycznego w historycznej dla Polski chwili dziejowej. Tym projektem jest ethos żołnierza, ucieleśniony w postaci młodego bohatera.

2.

Z kolei Ambrożek domobrońca Miroslava Krležy to, rzec można, przenicowana mitologia pokolenia wojennego. W trójdzielnie skomponowanym opowiadaniu chorwacki pisarz odsłania trzy stosunkowo krótkie etapy młodości swego bohatera: wojenną musztrę i walkę w okopach, pobyt w pałacu 
w okresie kuracji po odniesionym postrzale i wreszcie życie za frontem, w baraku dla inwalidów wojennych. Biografia Ambrożka nie podlega żadnej heroizacji, przeciwnie, opowiedziana została w trybie narracji ironicznej. Głównym sprawcą życiowej klęski chłopca wydaje się przypadek:

Ambrożek urodził się w samą noc Sylwestrową i gdyby się był spóźnił o kilka godzin zaledwie, nie potrzebowałby stawać z obecnym rocznikiem do wojska, lecz o całe 12 miesięcy później, a życie jego potoczyłoby się najprawdopodobniej zupełnie inną koleją.

Tak się jednak zdarzyło, że niemal jako gołowąs został domobranem i poszedł swą ciernistą drogą ku gwiazdom, jak się zazwyczaj idzie w epoce, kiedy te gwiazdy są - żołnierskimi gwiazdkami (Krleža 1939, 99).

Młody domobran, czyli „obrońca” urodził się w chorwackiej Tużnej Bistrze Zagórzańskiej, z matki - pięknej chłopki, która najpewniej wdała się $\mathrm{w}$ krótki romans $\mathrm{z}$ hrabią sławatyckim, właścicielem sadów owocowych, gdzie pracowała. Ambrożek nie był stworzony do wojny, zachwycał otoczenie niepospolitą urodą świadczącą o „uszlachetnionej, błękitnej krwi w jego żyłach płynącej" (Krleža 1939, 99). Inteligentny, bogobojny, wrażliwy, biedny. Z takim kapitałem ruszył do miasta, by zatrudnić się w charakterze boya hotelowego i był to już jakiś awans, wyższy szczebel w dążeniu do wymarzonego życia „wyjątkowego”, pańskiego. Tymczasem wybuchła wojna.

Ambrożek przybył zatem do swojej kompanii (,już pijany”), w której zdemoralizowani dowódcy niższego stopnia rozpoczynają brutalną musztrę za pomocą kar, razów, wyzwisk:

Spędzono rekrutów jak bydło, rzucono się na nich ze wszystkich stron, a teraz rozpoczną poskramianie tych zagórzańskich wieprzy, durniów, osłów i bałwanów.

- Słuchaj!

- Słuchaj, ty ścierwo! Djabli na twego ojca i matkę! Wal go, niech trzaśnie! Te buciory nie są twoje!

- Słuchaj! draniu przeklęty! Znowu symulujesz!

- Słuchaj! Wstrętny leniu! Daj mi szklankę wody!

- Słuchaj! Oczyść mi buty! Bo będziesz je lizał swym zagórzańskim jęzorem!

- Słuchaj! Łotrze Chrystusowy! Wciągnij ten swój kałdun! Cofnij spodnie, piersi naprzód! (Krleža 1939, 72).

Stłoczeni w obskurnym baraku rekruci żyją wilczym prawem, okradając się wzajemnie i szydząc z Ambrożka „fujary”. Uczą się strzelać, myją wychodki, sprzątają kancelarie i tylko niedziela jest ,jedynym, jasnym akordem”. W niedzielę Ambrożek idzie do kościoła, gdzie ksiądz w zagórzańskiej gwarze „mówi o dynastji, o krwi i o śmierci, która jest szczególnie chlubna właśnie na placu boju" (Krleža 1939, 80). Zagórzanie w swej prostej logice identyfikują państwo z austriackim cesarzem, któremu służą wiernie, jak służyli mu ich ojcowie i dziadowie. Propaganda cesarska wskazuje wroga: 
Serba, podsycając etniczną nienawiść, która staje się główną motywacją do walki, bo prosty żołnierz nie widzi szerzej mapy wojny i koalicyjnych sojuszy. Po pierwszej większej klęsce, gdy nie dochodzi do zawarcia pokoju, w kompanii szerzy się dezorientacja i defetyzm:

Co nam Rosjanie zawinili? Gdzie Zagórze, a gdzie Rosja, do ciężkiej cholery?

I teraz zapanował chaos w zagórzańskich głowach i czuje z nich każdy, że to są wiatraki, z czem im walczyć nakazują. Wiatraki - tak to pojmowali a i to rozumieli dobrze, że strawa otrzymywana nic nie jest warta, że są domobranami w lachmanach, bo to, w co ich ubrano, jest papierem i buty są z papieru, wszystko jest z pokrzyw, a jak rozmięknie, to się rozleci (Krleža 1939, 86).

Nietrudno dostrzec, że Krleža demaskuje absurd wojenny we wszystkich jego przejawach, realnych, jak też ideologicznych. Los domobrana rozpina się „między strawą a śmiercią”, żołnierz trwa w nudzie wojennej rutyny koszar lub okopów, przerywanej grzebaniem poległych towarzyszy. Z monotonii tej wyrywa Ambrożka postrzał, wskutek którego trafia do pociągu Czerwonego Krzyża, wywożącego rannych do różnych, mniej zapełnionych szpitali. Ambrożek długo czekał na swoją kolej, w rezultacie amputowano mu nogi i, nie dając większych szans na przeżycie, skierowano do Belwederu - barokowego pałacu Jej Książęcej Wysokości Marii Anuncjaty. Początkowo księżna, zafascynowana urodą chłopca, pielęgnuje go osobiście, choć opieka ta nabiera oznak perwersji. Podczas długich nocnych godzin spędzanych u łóżka na wpół przytomnego chłopca, utożsamia go z widzianym niegdyś posągiem Narcyza; rozpoczynają się pieszczoty i erotyczno-tanatyczne gry wyobraźni, księżna roi o tym, by posiąść lub zniszczyć ciało chłopca, aż wreszcie za radą spowiednika nagle opuszcza pałac i zostawia Ambrożka na niełasce losu. Dopiero wówczas odzyskuje on w pełni świadomość, dostaje gorączki, krzyczy, odczuwa paniczny strach. Przeżywa silny, fantomowy ból utraty - nie nóg, lecz księżnej jako przewodniczki do lepszego, „belwederskiego” losu:

I właśnie dlatego, że księżna unosiła się przed jego oczami, niby jakaś zasłona, tak, że z początku leżał zupełnie oszołomiony, a teraz nagle mu zasłonę zdarli i teraz to widzi dopiero, co mu się przygodziło - wściekł się Ambrożek na jaśnie panią i zaczął wygadywać głupstwa, że mu nogi odgryzła, że jest kurwą, co mu odgryzła nogi (Krleža 1939, 104).

Ambrożek na koniec trafia do plugawego siedliska wojennych kalek, odwiedzanego jedynie przez starą, wulgarną handlarkę-prostytutkę. Chłopiec czuje się „zgwałcony”, opuszczony, oszukany - i mimo to jego uwagę zaprząta jedynie „belwederska” przeszłość. Kuśtyka pod sklepowe witryny i wpatrując się w podobną do księżnej lalkę woskową, marzy o jej uśmiechu.

Można opowiadanie Krležy, sympatyka ideologii lewicowych, całkiem zasadnie umieścić w nurcie krytyki społecznej (pisarz po zakończeniu wojny brał udział w kampanii publicystycznej skierowanej przeciw „burżuazji”). 
Głębsze wydaje się nam ono w interpretacji symbolicznej, gdy księżna, metonimizująca wojnę jako siłę sprawczą gorzkiej adolescencji, stanie się uosobieniem fatum, od którego nie ma ucieczki. Jeszcze inaczej kształtują się znaczenia tej opowieści w kontekście literatury „straconego pokolenia”.

Chorwacki pisarz opowiada o zmarnowanym, bezsensownym życiu młodego domobrana, nie o straconym losie całej generacji. „Malowany chłopiec" został przez wojnę - jak w polskiej piosence - wybrany, lecz ów wybór ma sens ironiczny, nie bohaterski. Ambrożek przypadkowo trafia w wir wielkiej historii, której nie znał i nie rozumiał. Ironia losu wyraża się tu w motywie pragnienia „innego” życia, które na krótko zostało chłopcu ukazane i brutalnie odebrane. Kiedy jego rówieśnicy, jak na przykład Paweł Bäumer z powieści Remarque'a, tracą na wojnie nie tylko złudzenia (patriotyczne, miłosne, egzystencjalne), lecz nawet zdolność odczuwania emocji - Ambrożek nie przestaje tęsknić za „belwederskim”, pięknym światem. Bohaterowie Remarque’a stają się ofiarami ideologii, domobran Krležy zamiast ideologią żywi się mitem. To jednak nie wojna staje się sprawczynią utraty mitu, lecz wyidealizowana przez chłopięcą fantazję księżna.

Chorwacki pisarz wplata więc w wojenną opowieść nie tylko protest pacyfistyczny i społeczny, lecz także egzystencjalny morał o wszechpotędze absurdu i znikomości ludzkich dążeń do kształtowania losu. Krleža jest ironistą, bo narrator tej opowieści nie demonstruje jawnie współczucia, ani nie polaryzuje wyraźnie znaków wartości. Widzi scenerię wojny jako theatrum mundi, zaś malując jej obraz, posługuje się groteską, która nie łagodzi (jak na przykład w satyrycznych Przygodach dobrego wojaka Szwejka J. Haška), lecz potęguje odczucie egzystencjalnego absurdu.

3.

Utwory Struga i Krležy można objąć w komparatystycznej lekturze jako dwa biegunowo odmienne portrety bohaterów pokoleniowych. Motywem wspólnym pozostaje, powtórzmy, inicjacyjność doświadczenia wojennego oraz jego formacyjny charakter. Podobna jest również w obu utworach mitotwórcza funkcja postaci-przewodników w rytuałach przejścia chłopców do stanu dorosłości. Z istotnym zastrzeżeniem, że „przewodnicy” mają na bohaterów wpływ zupełnie różny. W Odznace za wierna służbę legendarny Komendant samym swoim istnieniem dodaje Sylwkowi wiary w celowość walki. W opowiadaniu Krležy natomiast Jej Książęca Wysokość Maria Anuncjata, krótko i dla zaspokojenia dwuznacznych pragnień pielęgnująca rannego Ambrożka w swoim Belwederze, na zawsze rujnuje młode życie.

Bohaterowie obu utworów na początku nie są jeszcze żołnierzami. Sylwek, niechętny szkolnej edukacji (której przerwanie przez wybuch wojny przyjmuje z widoczną ulgą), ma wyraźne skłonności pisarskie, nie rozstaje się więc z pamiętnikiem, przez dwa lata zapisując wydarzenia kolejnych dni, ale także coraz bardziej pogłębione ogólne refleksje. Ambrożek „na pastwisku czytywał Andersena” (Krleža 1939, 101), marząc o królach 
i księżniczkach, a pracując już w mieście, czytał także dzienniki i nawet chadzał do opery. Każdy więc - zgodnie z psychologią dorastania - ucieka od realności w krainę wyobrażeń, które formatują rzeczywistość i jednocześnie naddają jej wymiar idealny.

Wielka Wojna wyrywa chłopców z rodzinnych stron; Sylwka z polskiego Krakowa, Ambrożka z chorwackiego Zagórza. Sylwka-sierotę wychowywała dość majętna babka. Ambrożek także był sierotą, na chleb zaczął zarabiać jako boy hotelowy w Grazu. Główna różnica w modelowaniu biografii pokoleniowej najwyraźniej ujawnia się w finałach obu utworów. Sylwek umiera, lecz zdążył przebyć drogę pełnego rozwoju, doszedł do fazy tożsamościowej dojrzałości - zrozumiał, że naprawdę jest żołnierzem. Ambrożek przeszedł fazę kryzysu - i już się nie podniósł, jego życie toczy się więc w kierunku degradacji osobowości, regresji, beznadziejnego zastoju.

Przerwana za wcześnie młodość i bolesne zderzenie z realnością to rozpowszechniony po wojnie topos, spopularyzowany głównie przez powieść Remarque'a Na Zachodzie bez zmian. W Odznace za wierna służbę Andrzeja Struga przyjmuje on postać semantycznie „odwróconą", bo wprawdzie Sylwek po odniesieniu ran klatki piersiowej zapada na galopującą gruźlicę i umiera, lecz jednak przed samą śmiercią zdoła ujrzeć ukochanego wodza. W opowiadaniu Krležy samopoczucie Ambrożka symbolizuje pejzaż:

Deszcz leje, mrok zapada, i już zapalają się lampy na wystawach sklepowych, a żółtawe światło gazowe rozlewa się po asfalcie. Wszystko jest tak żałosne i puste, a dzwony biją i zmierzch szary i mglisty spływa i wlecze się pod parkanami, jak chora kotka (Krleža 1939, 109).

Wydawałoby się, że Strug również przedstawia Sylwka jako postać tragiczną. Tak jednak nie jest, bo w zakończeniu utworu pojawia się typowy dla polskiej literatury tego okresu romantyczny motyw patriotycznej ofiary:

Jeszcze w ogniu i klęskach bez miary tonie ojczyzna, ale wiem, że z martwych powstanie wielka, świetna i młoda. A przy tym największym szczęściu cóż znaczy moja dola? Więc niczego już nie chcę dla siebie. Serce mam pełne cichej radości (Strug 1957, 135).

Odznaka za wierna służbę powstaje z intencji heroizacji wojny jako walki o wyższe, wspólne dobro. Opowieść Andrzeja Struga o losach młodego Sylwka podtrzymuje taką patriotyczną narrację wojenną, która jest przedłużeniem romantycznej ideologii niepodległościowej. Kazimierz Wyka w obrachunkach z prozą międzywojenną pisał: „Pierwsza wojna światowa stanowiła nie doświadczenie realne, lecz jakiś mit patetyczny, którego cieniem chętnie się upajano" (Wyka 1974, 20). Natomiast Domobran Jambrek Miroslava Krležy reprezentuje inny wariant - demitologizacji wojny, bliższy na przykład Soli ziemi Józefa Wittlina (z 1935 roku).

Wielka Wojna zrodziła nie tylko nową wrażliwość etyczną, lecz także nowe formy $\mathrm{w}$ literaturze. Jednym $\mathrm{z}$ ciekawszych przykładów $\mathrm{z}$ kręgu 
kultury bałkańskiej jest mikropowieść rówieśnika Krležy, serbskiego pisarza - Miloša Crnjanskiego pt. Zapiski o Czarnojeviciu (Dnevnik o Čarnojeviću) z 1921 roku. Narrator nie czuje się tutaj podmiotem historii, nie dostrzega też żadnej teleologii w swoim losie. Mówi: „Żołnierzem jestem, nikim i niczym jestem i nic z tego, co się zdarzyło, nie rozumiem" (Crnjanski $1971,115)$. Dalej jednak pisarz rozwija w wojennej opowieści oryginalną koncepcję konsolacyjną, którą nazywa sumatraizmem. Egzotyczna, indonezyjska wyspa staje się mityczną figurą podszewki bytu, naznaczonego śmiercią, chaosem, absurdem. Sumatra to utopia, synonim energii, szczęścia, radości. Tam zawsze jest błękit i słońce, „tutaj” zawsze deszcz, błoto i mgła.

W Odznace za wierna służbe pojawia się - podobnie jak w zakończeniu Ognia Barbusse'a - heroiczny topos nienadaremnej ofiary. Crnjanski, analizując samopoczucie wojennego pokolenia, za pomocą trybu pytającego nadaje tej konsolacji znaczenie ironiczne:

My pomrzemy i nadejdzie lepszy wiek, zawsze nadchodzi. W zielonych obszarpanych szynelach, bladzi i uśmiechnięci będziemy włóczyć się ulicami. My nie chcemy niczego, nie żałujemy niczego, nie żałujemy niczego, prawda? (Crnjanski 1971, 142).

W wymiarze artystycznym proza Crnjanskiego ma wartość innowacyjną, ponieważ otwiera w literaturze bałkańskiej nurt awangardy, a nawet - jak twierdzą niektórzy badacze - zapowiada znacznie późniejszy postmodernizm. Można postawić pytanie, dlaczego mimo podobieństwa kontekstów historycznych (walka w obcej armii) tym pisarzom bałkańskim, których utwory zostały tu przywołane, udało się odnaleźć ton znacznie bardziej wiarygodny dla reprezentacji wojennego doświadczenia niż Strugowi czy innym autorom polskim? Odpowiedź zdaje się oczywista, chodzi bowiem o rangę tradycji romantycznej, szczególnie wysoką w naszej kulturze. Zarówno groteskowo-ironiczna konwencja opowiadania Krležy, jak i modernistyczna poetyka Zapisków o Czarnojeviciu, czyli amimetyczna zasada fragmentu, polifonicznej narracji i kompozycji otwartej, kształtuje się jako ekwiwalentna odpowiedź na traumatyczne doświadczenia Wielkiej Wojny. Jednak ten rodzaj eksperymentów, przekraczających paradygmat tradycji romantycznej, twórcy literatury polskiej podejmą dopiero po zakończeniu drugiej, równie strasznej wojny.

\section{Bibliografia}

Crnjanski Miloš, 1971, Zapiski o Czarnojeviciu, Cirlić-Straszyńska D. (przeł.), Warszawa.

Krleža Miroslav, 1939, Ambrożek domobrońca, w: Chorwacki bóg Mars, Gluck W. i Siennicka H. (przeł.), Benešić J. (przedmowa), Warszawa.

Olszewska Maria Jolanta, 2004, Człowiek w świecie Wielkiej Wojny. Literatura polska z lat 1914-1919 wobec I wojny światowej. Wybrane Zagadnienia, Warszawa. 
Remarque Erich Maria, 1974, Na Zachodzie bez zmian, Napierski S. (przeł.), Kraków.

Strug Andrzej, 1957, Odznaka za wierna służbę, Warszawa.

Wyka Kazimierz, 1974, Tragiczność, drwina i realizm, w: Pogranicze powieści, Warszawa.

\section{O Autorce:}

Anna Legeżyńska - prof. dr hab.; wykłada historię i teorię literatury XX i XXI wieku w Instytucie Filologii Polskiej na Uniwersytecie im. Adama Mickiewicza w Poznaniu. Autorka książek: Tłumacz i jego kompetencje autorskie. Na materiale powojennych tłumaczeń poezji A. Puszkina, W. Majakowskiego, I. Kryłowa i A. Błoka (Warszawa 1986; wyd. II, poszerzone: 1999), Dom i poetycka bezdomność w liryce współczesnej (Warszawa 1996), Wisława Szymborska (Seria „Czytani dzisiaj”, Poznań 1996 wyd. I, 1997 wyd. II i III), Gest pożegnania. Szkice o poetyckiej świadomości elegijno-ironicznej (Poznań 1999), Krytyk jako domokrążca. Lekcje literatury z lat 90. (Poznań 2002), Od kochanki do psalmistki... Sylwetki, tematy i konwencje liryki kobiecej (Poznań 2009). Współautorka syntezy Poezja polska po 1968 roku (z P. Śliwińskim, Warszawa 2000) i tomu pt. Literatura polska XX wieku (Seria: „Zrozumieć literature”” z B. Kaniewską i P. Śliwińskim, Poznań 2005). W swoim dorobku ma również współautorskie podręczniki akademickie i szkolne: Teoria literatury. Skrypt dla studiów zaocznych (z B. Kaniewską, Poznań 2002 wyd. I, 2003 wyd. II, 2005 wyd. III) oraz Skarbiec języka, literatury, sztuki (podręcznik z wypisami dla kl. I liceum ogólnokształcącego, z B. Chrząstowską, B. Kaniewską i in., Poznań 2002, 2003). 